Article

\title{
Anaerobic Co-Digestion of Kitchen Waste and Blackwater for Different Practical Application Scenarios in Decentralized Scale: From Wastes to Energy Recovery
}

\author{
Huihui Wang ${ }^{1,2}$, Zifu Li ${ }^{1,2, *}$, Xiaoqin Zhou ${ }^{1,2}$, Xuemei Wang ${ }^{1,2}$ and Siqi Zuo ${ }^{1,2}$ \\ 1 School of Energy and Environmental Engineering, University of Science and Technology Beijing, \\ Beijing 100083, China; g20188205@xs.ustb.edu.cn (H.W.); xiaoqinzhou@ustb.edu.cn (X.Z.); \\ b1910138@ustb.edu.cn (X.W.); s20170206@xs.ustb.edu.cn (S.Z.) \\ 2 Beijing Key Laboratory of Resource-oriented Treatment of Industrial Pollutants, University of Science and \\ Technology Beijing, Beijing 100083, China \\ * Correspondence: zifuli@ustb.edu.cn
}

Received: 30 July 2020; Accepted: 5 September 2020; Published: 13 September 2020

check for updates

\begin{abstract}
This study was performed to investigate the anaerobic digestion feasibility of kitchen waste and blackwater under different scenarios in laboratory tests. According to biochemical methane potential tests, when the kitchen waste to blackwater solid ratio was 1:1, the cumulative methane production reached the highest amount at $313.2 \mathrm{~mL} / \mathrm{g}$ volatile solids (VSs), which was $26.4 \%$ and $29.4 \%$ higher than the anaerobic monodigestion of kitchen waste and blackwater, respectively, indicating that the anaerobic codigestion of kitchen waste and blackwater had a synergetic effect. Furthermore, the effect of different initial total ammonia nitrogen concentrations in blackwater on anaerobic digestion was determined based on the above experimental results, thereby proving that reducing the total ammonia nitrogen concentration in blackwater can appropriately improve the efficiency of methane production. Therefore, anaerobic digestion is a suitable method for the biogas production of kitchen waste and blackwater. It is of great significance for the organic waste stream treatment of households in a decentralized scale, especially in rural areas.
\end{abstract}

Keywords: anaerobic codigestion; kitchen waste; blackwater; methane production; ammonia nitrogen inhibition

\section{Introduction}

The world's population is continuously increasing because of rapid urbanization. According to statistics, the world's population was close to 8 billion in August 2018 and is expected to exceed 9 billion by 2040 [1]. This rapid population increase has caused serious environmental problems because of large amounts of human-generated wastes, such as kitchen waste (KW) and blackwater (BW). These wastes cause huge environmental pollution problems and are also considered misplaced resources. In recent years, with people's emphasis on sustainable development, the interest for resource recovery technology has been increasing. Anaerobic digestion has been widely used to treat sewage and animal manure for many years, and this technique could be an important research issue to treat high concentration of organic wastes [2]. Daily household waste streams mainly consist of toilet waste (blackwater) and kitchen waste [2]. In China alone, tens of millions of tons of KW are produced every year. This volume of waste threatens the living environment and public health. However, KW is a good candidate for anaerobic digestion due to its high biodegradability and water content [3]. In recent 
years, the treatment of biomass waste using anaerobic digestion technology has gained importance because of the improvement of regulations on biomass waste treatment [4].

However, two waste flows of KW and BW fluctuate significantly in terms of composition and amount because of different lifestyles and changing seasons, and therefore their specific ratio is not fixed. Substrate supply cannot be guaranteed with consistent characters in the decentralized scale. Therefore, different scenarios need to be investigated at the decentralized scale. Some researchers reported that there are some problems with anaerobic digestion of a single material, such as easy acidification, low biogas production efficiency, and vulnerability to seasonal impacts $[5,6]$. The organic components in kitchen waste are easily degraded, and often cause the accumulation of volatile fatty acids (VFAs). Consequently, the $\mathrm{pH}$ value decreases, inhibiting the activity of methanogens, and the anaerobic digestion system becomes unstable [7]. The output of BW is huge, and the efficiency of resource utilization is low-the high degree of decentralization in rural areas especially brings difficulties to the treatment of BW. BW contains high organic nutrients and is a good candidate for bioenergy recovery through anaerobic digestion [8]. However, when BW is treated by anaerobic monodigestion, there may be problems such as ammonia suppression and low biogas production efficiency. Therefore, it may be used as a good raw material for codigestion with KW because of the high total ammonia nitrogen (TAN) concentration in urine, which can improve the buffer performance and supplement trace elements to facilitate the anaerobic digestion process $[9,10]$. This is essential for the efficient treatment of BW, which is the main household liquid waste stream. Limited studies have been conducted on KW and BW codigestion [10-12], and the feasibility of the codigestion of them has been proved. However, the important parameter of the mixing ratio still lacks detailed research, and the effect of the initial TAN concentration of BW on codigestion systems also needs further study.

The present study focuses on a feasibility assessment and optimal conditions of anaerobic digestion for biogas production using KW and BW, considering different scenarios at the decentralized scale. Biochemical methane potential (BMP) tests of each waste and their mixtures at different mixing total solid (TS) ratios were conducted to examine methane production performance during anaerobic digestion. In addition, cumulative methane production was simulated using the modified Gompertz equation, and it was highly fitted to the experimental data. Furthermore, promoting or inhibiting effect of different TAN and free ammonia nitrogen (FAN) concentrations in BW on the codigestion system was explored by adjusting the initial ammonia nitrogen concentration of BW to demonstrate that the proper control of ammonia concentration could benefit the anaerobic digestion process.

\section{Materials and Methods}

\subsection{The Sources of Substrate and Inoculum}

Kitchen waste $(\mathrm{KW})$ was composed of $60 \%$ processed kitchen waste and $40 \%$ raw kitchen waste. The processed kitchen waste was collected from a student dining hall in the University of Science and Technology Beijing. The main ingredients included rice, pasta, meat, fruit, and vegetables. Raw kitchen waste was made up of raw vegetable and fruit wastes. The mixed KW was crushed into a slurry with a size of 1-2 mm and stored in the fridge $\left(4^{\circ} \mathrm{C}\right)$. Blackwater (BW) was obtained from a movable dry toilet at the construction site of the University of Science and Technology Beijing. After collecting BW in a plastic bucket, a sieve with a pore size of $4 \mathrm{~mm}$ was used to filter out large pieces of toilet paper to avoid blocking the pipes. The BW was stored at $4{ }^{\circ} \mathrm{C}$ until used.

The inoculated sludge was obtained from a pilot anaerobic digestion system fed with waste activated sludge. The pilot-scale reactor is located in the wastewater treatment plant in Chaoyang District, Beijing. It was digested at room temperature for 7 days before use. The KW, BW, and inoculum main characteristics are listed in Table 1. 
Table 1. Main characteristics of kitchen waste, blackwater, and inoculum.

\begin{tabular}{cccc}
\hline & KW & BW & Inoculum \\
\hline TS (\%) & 25.1 & 6.7 & 6.0 \\
VS/TS (\%) & 90.2 & 78.5 & 48.8 \\
C (\%) & 46.7 & 43.2 & $/$ \\
H (\%) & 6.6 & 6.1 & $/$ \\
O (\%) & 44.2 & 45.8 & $/$ \\
N (\%) & 2.2 & 4.0 & $/$ \\
S (\%) & 0.3 & 0.9 & $/$ \\
C/N & 21.2 & 10.8 & $/$ \\
pH & 4.3 & 6.7 & 7.5 \\
COD (g/L) & 192.9 & 143.2 & $/$ \\
TAN (mg/L) & 635 & 4488 & $/$ \\
VFA (g/L) & 0.72 & 20.27 & $/$ \\
\hline
\end{tabular}

\subsection{Experimental Setup}

\subsubsection{Biochemical Methane Potential (BMP) Tests of Different Substrate Ratios}

In the BMP tests, according to the different TS ratios of KW and BW, five groups of anaerobic digestion experiments were performed, including the monodigestion of KW and BW. Table 2 shows the detailed arrangement. The ratio of substrate (i.e., $\mathrm{KW}$ and BW) to inoculum was $0.5 \mathrm{~g} \mathrm{VS} / \mathrm{g}$ vs. [13]. To recognize the contribution of organic matters in the inoculum, only inoculum sludge was used for anaerobic digestion as the blank control group. Then, the observed biogas production (volumetric test) of the experimental group subtracted the biogas production of the blank control group to get the net biogas production of the substrate. Glass bottles with a total volume of $500 \mathrm{~mL}$ were used as reactors for anaerobic digestion, and their effective volume was $400 \mathrm{~mL}$. The BMP tests were carried out at $38 \pm 1{ }^{\circ} \mathrm{C}$ in a water bath for 30 days. There was no adjustment of $\mathrm{pH}$ during the experiment. The BMP reactors were shaken manually twice a day. The anaerobic test for each group was performed in triplicate. The production of biogas and methane was measured daily, and samples were taken regularly to determine the physical and chemical indicators such as $\mathrm{pH}$, TAN, VFA.

Table 2. Different prepared substrates for the biochemical methane potential (BMP) experiments.

\begin{tabular}{ccccccc}
\hline & A & B & C & D & E & Control \\
\hline KW:BW based on TS & $4: 0$ & $3: 1$ & $1: 1$ & $1: 3$ & $0: 4$ & $/$ \\
Mixture (g) & 400 & 400 & 400 & 400 & 400 & 400 \\
KW (g) & 20.3 & 15.7 & 10.7 & 5.5 & 0.0 & 0.0 \\
BW (g) & 0.0 & 19.7 & 40.5 & 62.5 & 85.7 & 0.0 \\
Inoculum (g) & 314.8 & 312.6 & 310.2 & 308.1 & 305.4 & 400 \\
Water (g) & 64.9 & 52.0 & 38.6 & 23.9 & 8.9 & 0.0 \\
TS of mixture (\%) & 6.0 & 6.0 & 6.0 & 6.0 & 6.0 & 6.0 \\
VS of mixture (g) & 4.6 & 4.6 & 4.6 & 4.6 & 4.5 & $/$ \\
pH of mixture & 7.9 & 7.7 & 7.7 & 7.6 & 7.5 & 7.5 \\
\hline
\end{tabular}

\subsubsection{Effect of Blackwater Initial Total Ammonia Nitrogen Concentration on Codigestion}

Additional BMP tests were conducted to investigate the potential impact of the initial TAN concentration of BW on the methanogenesis process when the TS ratio of KW and BW was 1:1. The TAN of the original BW was $4488 \mathrm{mg} / \mathrm{L}$. According to the method of a previous study [14], the membrane absorption method was used to reduce the initial TAN concentration of BW to 1541 and $2388 \mathrm{mg} / \mathrm{L}$. Moreover, a certain amount of $\mathrm{NH}_{4} \mathrm{Cl}$ was added to the raw $\mathrm{BW}$ to increase the TAN concentration to the targeted $6318 \mathrm{mg} / \mathrm{L}$. The detailed BW initial TAN concentration settings of four groups are shown in Table 3. Reactors, experimental temperature, and experimental duration are the same as Section 2.2.1. The experiments were conducted in triplicate. 
Table 3. The initial total ammonia nitrogen (TAN) concentration and $\mathrm{pH}$ value of blackwater in different experimental groups.

\begin{tabular}{ccccc}
\hline & Low & Middle & Raw & High \\
\hline TAN $(\mathrm{mg} / \mathrm{L})$ & 1541 & 2388 & 4488 & 6318 \\
$\mathrm{pH}$ & 6.2 & 6.2 & 6.1 & 6.2 \\
\hline
\end{tabular}

\subsection{Analysis and Calculations}

\subsubsection{Analytical Methods}

The total solids (TSs) and volatile solids (VSs) were measured using standard techniques [15]. The $\mathrm{pH}$ value was detected using a Hach $\mathrm{pH}$ meter (HQ30d). The $\mathrm{C}$ and $\mathrm{N}$ contents were determined with an elemental analyzer (vario EL cube, Elementar, Frankfurt, Germany). The concentrations of the total ammonia nitrogen (TAN), chemical oxygen demand (COD), and soluble chemical oxygen demand (SCOD) were determined by kits and the Hach DR 2800 Portable spectrophotometer, respectively. The free ammonia nitrogen (FAN) concentration was calculated based on the TAN concentration, $\mathrm{pH}$, and temperature using the following equation [16].

$$
\mathrm{NH}_{3}(\mathrm{FAN})=1.214 \times \mathrm{TAN} \times\left(1+\frac{10^{-\mathrm{pH}}}{10^{-\left(0.09018+\frac{2729.92}{\mathrm{~T}(\mathrm{~K})}\right)}}\right)^{-1}
$$

The liquid samples taken regularly were centrifuged at $6000 \mathrm{rpm}$ for $20 \mathrm{~min}$, and the supernatant was filtered using a $0.45 \mu \mathrm{m}$ membrane filter. Subsequently, the filtrate was analyzed with a gas chromatograph (GC-8600, Beijing, China) coupled with a flame ionization detector (FID) to calculate the volatile fatty acid (VFA) concentration. The biogas volume was measured by a $200 \mathrm{~mL}$ plastic syringe, and the methane content was determined using a biogas analyzer (Geotechnical (UK) producer Ltd., Gloucester, UK). The measured methane volume was corrected to standard temperature and pressure.

\subsubsection{Kinetic Data Analysis}

Some studies have successfully used the Gompertz model [17] to simulate the methanogenesis process $[18,19]$. In this study, the cumulative methane production curves were also fitted using the modified Gompertz equation, as described below:

$$
\mathrm{B}_{\mathrm{t}}=\mathrm{B}_{\mathrm{m}} \times \exp \left\{-\exp \left[\frac{\mathrm{R}_{\mathrm{m}} \times \mathrm{e}}{\mathrm{B}_{\mathrm{m}}}(\lambda-\mathrm{t})+1\right]\right\}
$$

where $B_{t}$ is the cumulative methane production per unit weight of vs. (mL/g VS) at a given time $t$; $B_{m}$ is the maximum methane potential of per unit weight vs. (mL/g VS) at the end of incubation; $t$ is time (day); $R_{m}$ is the maximum methane production rate of per unit weight vs. ( $\mathrm{mL} / \mathrm{g} \mathrm{VS} /$ day); $\lambda$ is the lag phase time (day); e is the base of natural logarithms (i.e., 2.71828). The values of $B_{m}, R_{m}$, and $\lambda$ were calculated using a nonlinear curve fit program in Origin 2017 (Northampton, MA, USA).

\subsubsection{Synergistic Effect}

The synergistic effect of anaerobic codigestion reflects the enhancement of codigestion between two materials. The synergy index (SI) was defined as the ratio of the tested $\mathrm{BMP}\left(\mathrm{BMP}_{\mathrm{T}}\right)$ to the estimated $\mathrm{BMP}\left(\mathrm{BMP}_{\mathrm{E}}\right)$ (i.e., the ratio of the $\mathrm{BMP}_{\mathrm{T}}$ of codigestion to the $\mathrm{BMP}_{\mathrm{E}}$ of codigestion based on the vs. mass of each substrate in the mixture and the results of monodigestion). SI above and below 1 indicate synergistic and antagonistic effects, respectively [20]. In this study, the $\mathrm{BMP}_{\mathrm{E}}$ and $\mathrm{SI}$ of the anaerobic codigestion experiment were calculated as follows [21]:

$$
\mathrm{BMP}_{\mathrm{E}}=\left(\mathrm{BMP}_{\mathrm{T}-\mathrm{KW}} \times \mathrm{VS}_{\mathrm{KW}}+\mathrm{BMP}_{\mathrm{T}-\mathrm{BW}} \times \mathrm{VS}_{\mathrm{BW}}\right) /\left(\mathrm{VS}_{\mathrm{KW}}+\mathrm{VS}_{\mathrm{BW}}\right)
$$




$$
\mathrm{SI}=\mathrm{BMP}_{\mathrm{T}} / \mathrm{BMP}_{\mathrm{E}}
$$

where $\mathrm{BMP}_{\mathrm{T}-\mathrm{KW}}$ and $\mathrm{BMP}_{\mathrm{T}-\mathrm{BW}}$ indicate the tested monodigestion $\mathrm{BMP}$ of $\mathrm{KW}$ and $\mathrm{BW}$, respectively. vs. is the vs. mass of the different substrates, and the subscripts indicate the type of substrate.

\section{Results and Discussion}

\subsection{Effects of Different Ratios of Two Substrates on Anaerobic Codigestion}

\subsubsection{Methane Production}

The methane production of the 30-day anaerobic digestion experiment of kitchen waste (KW) and blackwater (BW), including daily and cumulative methane production of the five groups of tests, are shown in Figure 1, where A, B, C, D, and E correspond to 247.0, 253.4, 313.2, 296.4, and 242.6 mL/g VS. The findings are lower than the methane production of the previous study (410-680 mL/g VS) [22-24], because of the difference in raw materials and reaction conditions. Compared with KW and BW monodigestion, the methane production of codigestion increased by $2.6 \%-29.4 \%$. Because anaerobic codigestion not only supplemented the nutrients required by microorganisms but also increased the buffer capability compared with monodigestion [25]. Thus, it was more conducive to improving the utilization of microorganisms by organic matter.
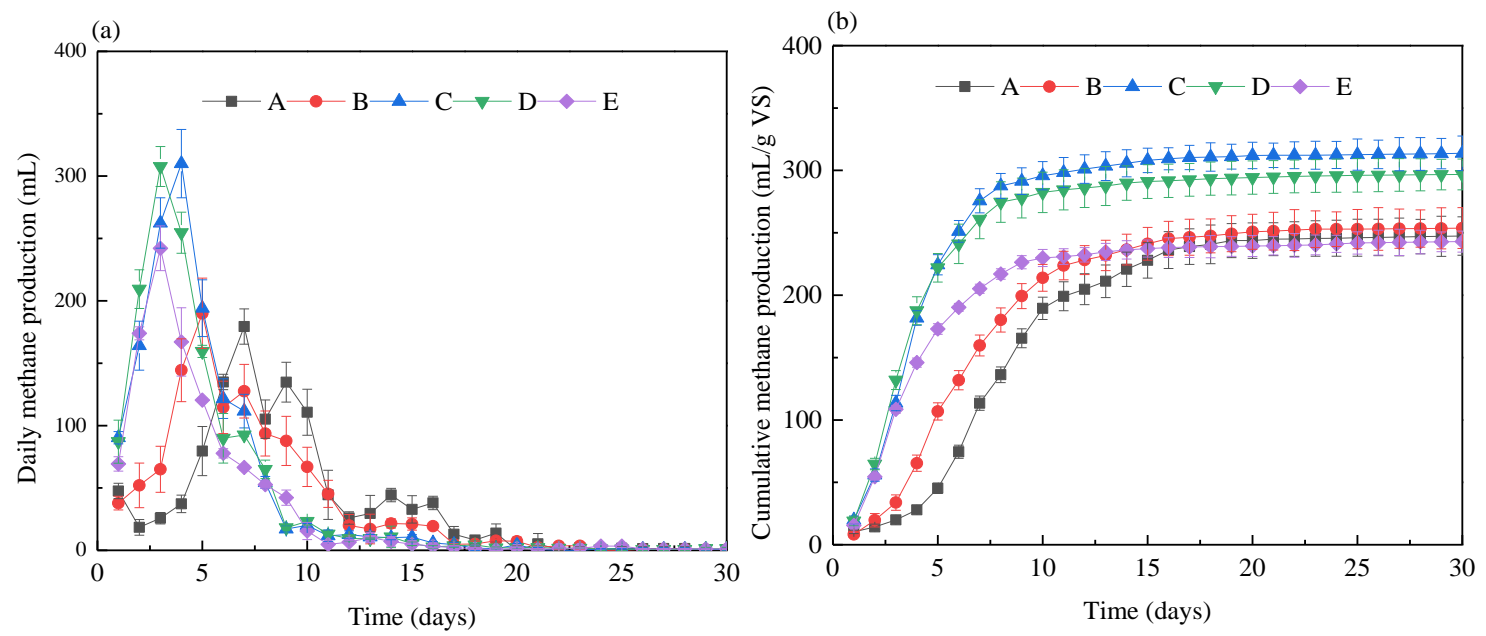

Figure 1. (a) Daily methane production and (b) cumulative methane production in the experimental BMP runs (the mixing ratios of kitchen waste and blackwater based on total solid (TS) content in groups A-E are 4:0, 3:1, 1:1, 1:3, and 0:4, respectively).

Figure 1a shows that when the KW was digested alone, the initial daily methane production was low, which may be due to the fact that the decreased $\mathrm{pH}$ value affected the activity of methanogens in the anaerobic digestion system. Given the buffer effect of the inoculum on the system and the degradation of the $\mathrm{N}$-containing compounds in $\mathrm{KW}$, the $\mathrm{pH}$ value gradually increased to a level that is suitable for the growth of microorganisms. Thus, the metabolic activity of microorganisms was enhanced, then methane production was significantly increased. In addition to the peak on the 7th day, small peaks were reached on the 9th and 14th day, possibly due to the continuous decomposition of macromolecular organic compounds in KW to further increase methane production. When a small amount of BW was added, the methane production increased, which may be the reason why BW improved the buffering of the anaerobic digestion system and the microorganism activity. With the increase in BW proportion, the C, D, and E groups rapidly produced methane at the beginning and peaked on the third or fourth day, possibly due to the high content of VFAs in BW, which provided sufficient nutrients for microbial methanogenesis. The complex organic compounds content in BW, which determines the high BW content, was low, and had a rapid digestion process. Subsequently, 
biogas production declined rapidly. That is, no more peaks appeared again, and gas production ended in approximately 10 days; such an observation is consistent with the previous study [23]. The 30-day average methane content in group A was 57.9\%, which was the highest among the five groups, whereas the average methane content in the four other groups was $56 \pm 1 \%$, indicating that $\mathrm{KW}$ and BW are ideal anaerobic digestive substrates with insignificant differences.

\subsubsection{Degradation of Organic Matter}

TS, VS, and COD were measured at the beginning and end of the experiment under different material ratios, and the removal rate was calculated (Table 4). The initial TS of all the tests was maintained at $6 \%$, i.e., $60 \mathrm{~g} / \mathrm{L}$. The TS removal rate of group A was up to $74.7 \%$. Moreover, except for group $\mathrm{C}$, the TS removal rate showed a downward trend as a whole with the increase in BW content. Solid organic matter was gradually degraded into a soluble substance and then consumed by the digestion process because a large part of organic matter in KW exists in solid form, as the experiment proceeded, thereby exhibiting a high TS degradation rate. However, the solid organic matter content in BW was relatively low [24], thereby decreasing the removal rate of TS. The vs. content in nearly all the test groups was $11.5 \mathrm{~g} / \mathrm{L}$, except for group E, which was $11.3 \mathrm{~g} / \mathrm{L}$. The changing trend of the vs. removal rate of all experiments was almost the same as that of the TS. Except for the highest vs. removal rate of $74.8 \%$ in group $\mathrm{A}$ and group $\mathrm{C}$, the removal rate of vs. showed a downward trend with the increase in BW content, and the lowest rate was only $54.9 \%$. From the change in the COD, as the proportion of BW increased, the COD degradation rate of group D gradually increased to $56.1 \%$, whereas the COD removal rate of group E only with BW decreased slightly to $51.5 \%$. The reason is that complex organic compounds, such as lipids in KW, are not easily degraded, thereby resulting in a low COD removal rate. However, the VFA content in BW was high. Thus, it was easy to decompose and use by microorganisms during the experiment. Therefore, as the content of BW increased, the degradation rate of COD increased. However, when only BW was used, the removal rate might be reduced because of ammonia nitrogen suppression. From the removal rates of TSs, VSs, and COD, the anaerobic codigestion of KW and BW had more advantages than anaerobic monodigestion.

Table 4. Variations of TSs, VSs, and COD before and after the experiments under different ratios of kitchen waste and blackwater.

\begin{tabular}{cccccc}
\hline & A & B & C & D & E \\
\hline $\mathrm{COD}_{\text {initial }}(\mathrm{g} / \mathrm{L})$ & 4.8 & 4.9 & 5.5 & 5.7 & 6.6 \\
$\mathrm{COD}_{\text {final }}(\mathrm{g} / \mathrm{L})$ & 2.9 & 2.6 & 2.8 & 2.5 & 3.2 \\
$\mathrm{COD}_{\text {rr }}(\%)$ & 39.6 & 46.9 & 49.1 & 56.1 & 51.5 \\
$\mathrm{TS}_{\text {initial }}(\mathrm{g} / \mathrm{L})$ & 60.0 & 60.0 & 60.0 & 60.0 & 60.0 \\
$\mathrm{TS}_{\text {final }}(\mathrm{g} / \mathrm{L})$ & 15.2 & 25.4 & 23.3 & 32.2 & 35.6 \\
$\mathrm{TS}_{\text {rr }}(\%)$ & 74.7 & 57.7 & 61.2 & 46.3 & 40.7 \\
$\mathrm{VS}_{\text {initial }}(\mathrm{g} / \mathrm{L})$ & 11.5 & 11.5 & 11.5 & 11.5 & 11.3 \\
$\mathrm{VS}_{\text {final }}(\mathrm{g} / \mathrm{L})$ & 2.9 & 3.2 & 2.9 & 4.3 & 5.1 \\
$\mathrm{VS}_{\text {rr }}(\%)$ & 74.8 & 72.2 & 74.8 & 62.6 & 54.9 \\
\hline
\end{tabular}

rr: the removal rate.

\subsubsection{System Stability Analysis}

Many factors, such as the concentrations of VFA and ammonia nitrogen, may disturb the stability of the anaerobic digestion system [5,23]. Moreover, FAN can easily penetrate the microbial cell membrane, thereby altering the $\mathrm{pH}$ and inhibiting some enzymatic reactions [14]. KW has a high $\mathrm{C} / \mathrm{N}$, and is rich in easily degradable carbohydrates. Rapid anaerobic digestion can easily cause the accumulation of VFA, which has a toxic effect on microorganisms [5]. However, the C/N of BW was relatively low, and the ammonia nitrogen concentration was very high. The methanogenic microorganisms were very sensitive to a high ammonia content, and the previous experimental results reported that the inhibition 
concentration of TAN ranged widely from 1.5 to $7.0 \mathrm{~g} / \mathrm{L}$ [26], and the FAN inhibition concentration varied from 45 [27] to $2473 \mathrm{mg} / \mathrm{L}$ [28] in different treatment systems.

At the beginning of the experiment, the concentration of VFA increased rapidly and reached its peak in 2 days because of the rapid progress in hydrolysis and acidification (Figure 2d). Thus, the $\mathrm{pH}$ value decreased rapidly, especially in groups $\mathrm{A}$ and $\mathrm{B}$, which have high $\mathrm{KW}$ content. The $\mathrm{pH}$ decreased from the initial 7.7 to 6.8 (Figure 2a), and the concentration of TAN and FAN also rapidly reduced to the lowest point (Figure $2 \mathrm{~b}, \mathrm{c}$ ). Given that the $\mathrm{pH}$ of groups $\mathrm{A}$ and $\mathrm{B}$ was too low, the activity of methanogenesis was inhibited, and the lag period increased, thereby reaching the peak of methane production on the seventh and fifth day (Figure 1a). Although the $\mathrm{pH}$ value of groups $\mathrm{C}, \mathrm{D}$, and $\mathrm{E}$ decreased, they were still in a suitable stage for methanogens. Thus, methane production increased rapidly, all reaching the peak of gas production in the first 4 days. Except for the rapid decrease in TAN caused by the rapid hydrolysis and acidification in the initial stage, the concentration of TAN showed a slight increase with minimal fluctuation after 2 days until the end of the experiment. With the increase in the added proportion of BW, the concentration of TAN and FAN gradually increased. The FAN concentration in groups $A$ and $B$ in the first 15 days was less than $150 \mathrm{mg} / \mathrm{L}$, which did not inhibit the methanogenesis process. In groups C, D, and E, the FAN reached a small peak on the fourth day at above $200 \mathrm{mg} / \mathrm{L}$ but did not have an immediate inhibitory effect on methanogens. After 10 days, the increasing concentration of FAN produced the inhibition of methanogens. In addition, the VFA content available for microorganisms was close to zero. Thus, methane production basically ended in 10 days.

During the anaerobic digestion process, VFA is the main intermediate substance that produces biogas, mainly including acetic acid, propionic acid, butyric acid, and valeric acid [29,30]. Acetic acid and butyric acid are ideal substrates for methanogenesis, whereas propionic acid is easily accumulated and is not suitable for methanogens. As shown in Figure $2 \mathrm{~d}$, when all trials were in the methane production stage, acetic and butyric acids always accounted for the majority of VFAs. Moreover, methane production decreased when VFAs were mainly composed of propionic acid. From the concentration of VFA and the change in methanogenesis, the VFAs of groups A and B accumulated in the first 2 days and exceeded $3000 \mathrm{mg} / \mathrm{L}$, and methanogens were inhibited. Since then, the ammonia nitrogen concentration increased, thereby improving the buffer capacity of the anaerobic digestion system. The activity of methanogens increased, and the methane production continued to increase. In groups $\mathrm{C}, \mathrm{D}$, and $\mathrm{E}$, ammonia nitrogen played a good buffering role because of the higher ratio of BW. Therefore, no inhibition effect was found though the concentration of VFA was higher than $2000 \mathrm{mg} / \mathrm{L}$. This result showed that KW and BW anaerobic codigestion was feasible.
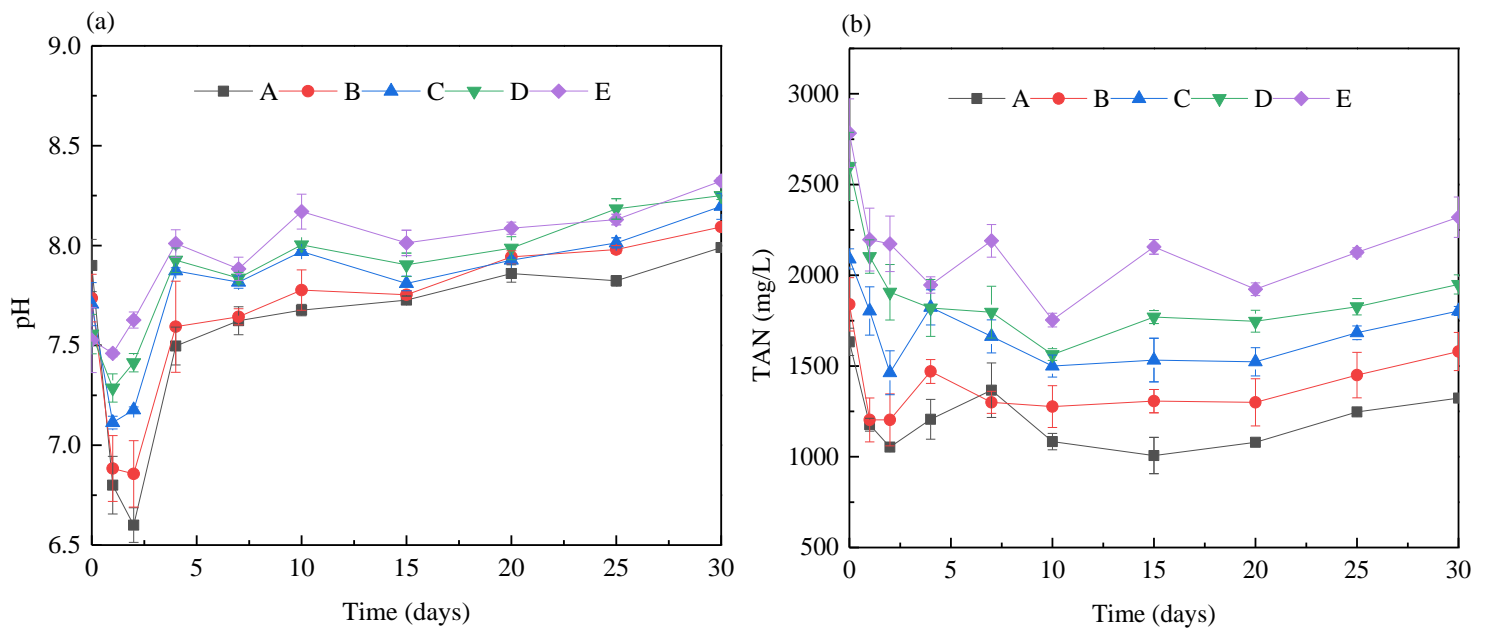

Figure 2. Cont. 

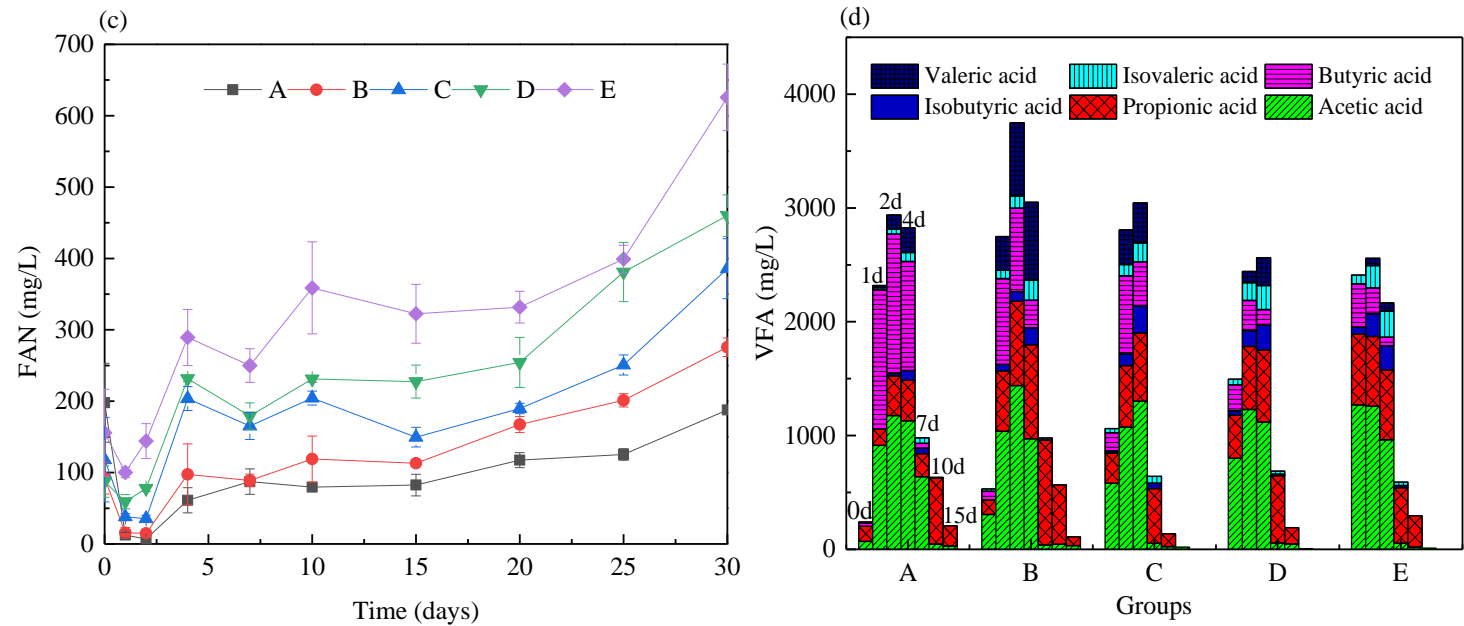

Figure 2. Variations of $\mathrm{pH}$, TAN, free ammonia nitrogen (FAN), and volatile fatty acids (VFAs) during anaerobic codigestion (the mixing ratios of kitchen waste and blackwater based on TS content in groups A-E are 4:0, 3:1, 1:1, 1:3, and 0:4, respectively): (a) pH, (b) TAN, (c) FAN, and (d) VFAs.

\subsubsection{Kinetics of Anaerobic Codigestion}

The results of using the modified Gompertz equation to simulate the tested methane production of each group are presented in Figure 3 and Table 5. The test cumulative methane production curve can be estimated by the equation with high degrees of fitting $\left(R^{2}>0.995\right)$. The lag-phase time $(\lambda)$ value of group A was 3.20 days, and those of groups B, C, D, and E were 1.83, 1.04, 0.81, and 0.63 days, respectively. The lag period was shortened with the increase in the proportion of BW. Compared with group $A$, the lag-phase time $(\lambda)$ value of group $C$ was reduced by $67.5 \%$, indicating that the TS ratio 1:1 of KW and BW was proper for accelerating their anaerobic digestion. The results show that the codigestion system was beneficial in terms of increasing the activity of methanogens, thereby improving the efficiency of anaerobic digestion [31].

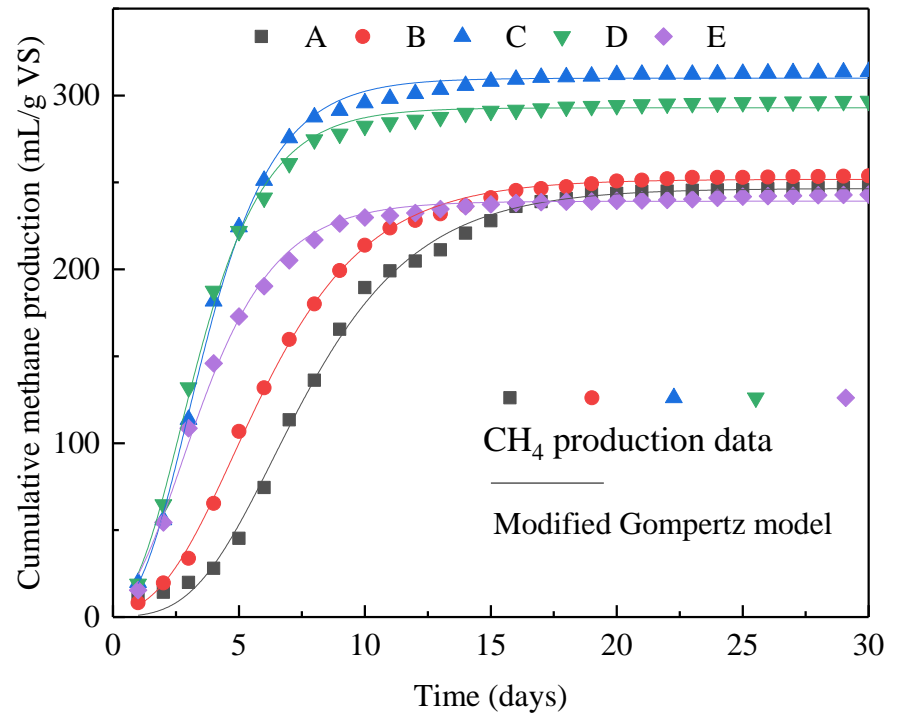

Figure 3. The fitting of the Gompertz model to the cumulative methane production curve of the experimental groups (the mixing ratios of kitchen waste and blackwater based on TS content in groups A-E are 4:0, 3:1, 1:1, 1:3, and 0:4, respectively). 
Table 5. Kinetic parameters of the modified Gompertz equation for methane production.

\begin{tabular}{ccccc}
\hline & $\mathbf{B m}(\mathbf{m L} / \mathbf{g}$ VS) & $\mathbf{R m}(\mathbf{m L} / \mathbf{g} \mathbf{~ V S} / \mathbf{d})$ & $\boldsymbol{\lambda}(\mathbf{d})$ & $\mathbf{R}^{\mathbf{2}}$ \\
\hline $\mathrm{A}$ & 246.55 & 28.86 & 3.20 & 0.9970 \\
$\mathrm{~B}$ & 251.79 & 31.56 & 1.83 & 0.9987 \\
$\mathrm{C}$ & 309.98 & 59.80 & 1.04 & 0.9975 \\
$\mathrm{D}$ & 292.91 & 57.85 & 0.81 & 0.9965 \\
$\mathrm{E}$ & 239.20 & 42.32 & 0.63 & 0.9955 \\
\hline
\end{tabular}

\subsubsection{Synergistic Effect}

Figure 4 shows the $\mathrm{BMP}_{\mathrm{T}}, \mathrm{BMP}_{\mathrm{E}}$, and synergy index of the $\mathrm{BMP}$ experiments. The synergy index of the three groups of anaerobic codigestion tests was all greater than 1, proving that $\mathrm{KW}$ and $\mathrm{BW}$ anaerobic codigestion had synergistic effects. The synergy index of group C, which is 1.28 , is the largest. It may be because the anaerobic codigestion system had the best buffering capability when the TS ratio of KW and BW was 1:1, and there was no ammonia inhibition, which was most conducive to methane production. The synergy index of groups B and D are 1.03 and 1.22, respectively, which showed that the best mix ratio of KW and BW existed, and the synergy was more evident when the TS ratio of BW was $50 \%$ or higher. The synergistic effect may be due to the good buffering performance in the codigestion system, and the activities of microorganisms were enhanced by supplementing trace elements [32-34].

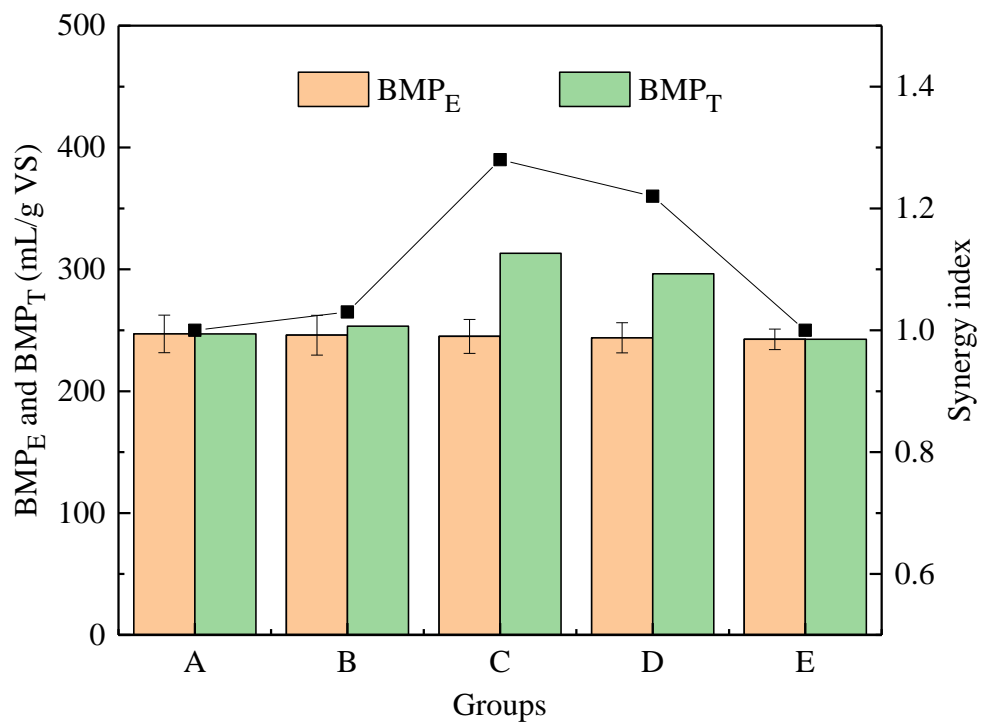

Figure 4. Comparison among $\mathrm{BMP}_{\mathrm{T}}, \mathrm{BMP}_{\mathrm{E}}$, and synergy index of the $\mathrm{BMP}$ tests (the mixing ratios of kitchen waste and blackwater based on TS content in groups A-E are 4:0, 3:1, 1:1, 1:3, and 0:4, respectively).

\subsection{Effect of Blackwater Initial Total Ammonia Nitrogen Concentration}

\subsubsection{Methane Production}

The ammonia nitrogen concentration has a significant effect on anaerobic digestion. However, if the substrate's ammonia nitrogen concentration exceeds a specific range, it is no longer suitable for anaerobic digestion. The initial TAN concentration of BW was adjusted to 1541,2388 , and $6318 \mathrm{mg} / \mathrm{L}$, and that of the raw BW was $4488 \mathrm{mg} / \mathrm{L}$ to investigate whether the initial TAN concentration of BW affected the methanogenic performance of KW and BW codigestion. Figure 5 shows that the difference of methane production is evident when the initial TAN concentration of BW changes. The cumulative methane production of the raw BW experimental group was $301.6 \mathrm{~mL} / \mathrm{g}$ VS. The cumulative methane production of the low and the middle TAN concentration group was 332.4 and $382.4 \mathrm{~mL} / \mathrm{g} \mathrm{VS}$, increased by $10.2 \%$ and $26.8 \%$, respectively. However, in the experimental group with a high concentration of 
initial TAN in BW, the cumulative methane production was only $160.3 \mathrm{~mL} / \mathrm{g}$ VS, which was $46.9 \%$ lower than the raw BW group. The result shows that reducing the initial TAN concentration of BW to a certain extent is very important to increase methane production, because it is conducive to improve hydrolysis efficiency which is considered the rate-limiting step $[35,36]$ during the anaerobic digestion of solid organic matter.
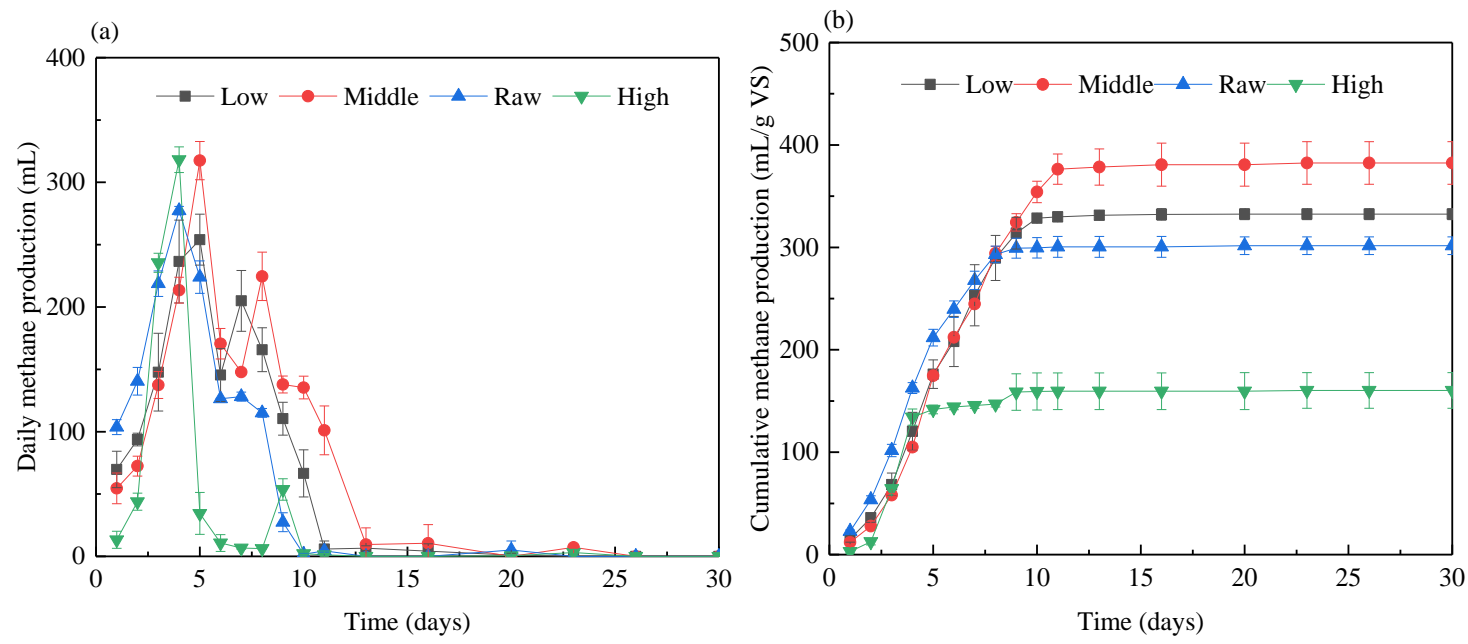

Figure 5. (a) Daily methane production and (b) cumulative methane production with different blackwater initial TAN concentrations (Low, Middle, Raw, and High represent that the blackwater initial TAN concentrations are 1541, 2388, 4488, and $6318 \mathrm{mg} / \mathrm{L}$, respectively).

\subsubsection{System Stability}

Figure 6 shows the variations of $\mathrm{pH}$, TAN and FAN with different $\mathrm{BW}$ initial TAN concentrations. In the initial test period, hydrolysis and acidification did not cause large fluctuations in $\mathrm{pH}$, and the activity of methanogens was high. With the degradation of nitrogen compounds, the TAN concentration increased, and the $\mathrm{pH}$ value increased above 8.0 after 5 days, which was not suitable for the growth of methanogens. The increase in TAN and $\mathrm{pH}$ values increased the FAN concentration, and methanogens were inhibited when FAN exceeded a specific concentration. The experimental group, in which the initial TAN concentration of BW was $6318 \mathrm{mg} / \mathrm{L}$, was severely suppressed on the fourth day, the concentrations of TAN and FAN reached 1575 and $176 \mathrm{mg} / \mathrm{L}$, respectively. At this time, the FAN had a serious toxic effect on methanogens, which led to a dramatic decrease after reaching the gas production peak on the fourth day, and the production of methane on the fifth day was close to zero. The experimental groups with initial TAN concentrations of 1541 and $2388 \mathrm{mg} / \mathrm{L}$ were less affected, and the methane production were higher. The reason may be due to the reduction in the inhibition effect of methanogens while playing a better buffering role and forming a dynamic equilibrium with VFA. When the TAN concentration was too low, the buffering effect weakened, which affected the progress of methane production. However, achieving the best balance between the ammonia nitrogen concentration and VFA concentration to achieve the highest gas production needs further exploration. 

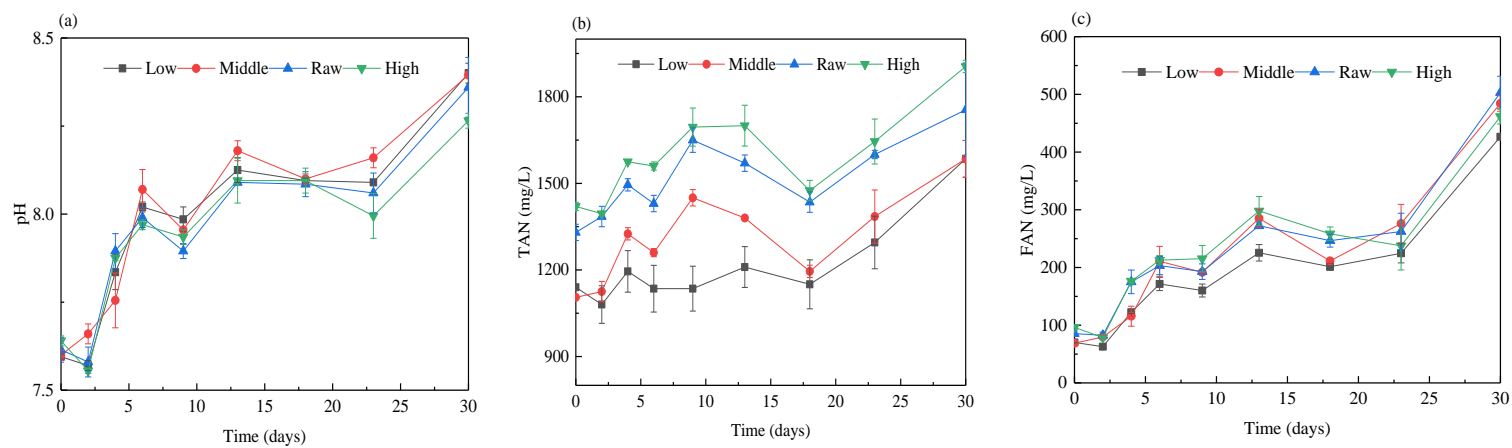

Figure 6. Variations of $\mathrm{pH}, \mathrm{TAN}$, and FAN with different blackwater BW initial TAN concentrations (Low, Middle, Raw, and High represent the BW initial TAN concentration are 1541, 2388, 4488, and $6318 \mathrm{mg} / \mathrm{L}$, respectively): (a) $\mathrm{pH},(\mathbf{b}) \mathrm{TAN}$, and (c) FAN.

\section{Conclusions}

Our experiment results demonstrated the feasibility of the anaerobic digestion of KW and BW. When the TS ratio of KW and BW was 1:1, the maximum methane production was $313.2 \mathrm{~mL} / \mathrm{g}$ VSs, which increased by $26.8 \%$ and $29.4 \%$ compared with digestion alone of KW and BW. In addition, a study on the effect of different initial TAN concentrations in BW on codigestion indicated that the proper reduction in TAN concentration in BW is beneficial in terms of increasing methane production. However, an extremely low TAN concentration decreases methane production because of the lack of a sufficient buffer capacity.

Author Contributions: Conceptualization, H.W., Z.L. and X.Z.; methodology, H.W.; software, H.W.; formal analysis, H.W.; investigation, H.W. and X.W.; resources, Z.L.; data curation, H.W.; writing-original draft preparation, H.W.; writing-review and editing, Z.L.; visualization, H.W. and S.Z.; supervision, X.Z.; project administration, Z.L. and X.Z.; funding acquisition, Z.L. All authors have read and agreed to the published version of the manuscript.

Funding: This research was funded by the National Key Research and Development Plan (2019YFC0408700), the International Scientific and Technological Cooperation and Exchange Projects (2016YFE0115600), the Beijing Science and Technology Project (Z181100002418016), and the Fundamental Research Funds for the Central Universities (FRF-TP-19-020A1; FRF-AT-20-03).

Acknowledgments: This research was supported by the Beijing Key Laboratory of Resource-oriented Treatment of Industrial Pollutants, International Science and Technology Cooperation Base for Environmental and Energy Technology of MOST.

Conflicts of Interest: The authors declare no conflict of interest.

\section{References}

1. United Nations. World Population Prospects 2017; United Nations: New York, NY, USA, 2017.

2. Kujawa, K.; Elmitwally, T.A.; Gaillard, A.; Leeuwen, V.M.; Zeeman, G. Co-digestion of concentrated black water and kitchen refuse in an accumulation system within the DESAR (decentralized sanitation and reuse) concept. Water Sci. Technol. 2003, 48, 121-128. [CrossRef]

3. Li, Y.; Jin, Y.; Li, J.; Li, H.; Yu, Z. Effects of thermal pretreatment on the biomethane yield and hydrolysis rate of kitchen waste. Appl. Energy 2016, 172, 47-58. [CrossRef]

4. Sun, Z.; Liu, K.; Tan, L.; Tang, Y.; Kida, K. Development of an efficient anaerobic co-digestion process for garbage, excreta, and septic tank sludge to create a resource recycling-oriented society. Waste Manag. 2017, 61, 188-194. [CrossRef] [PubMed]

5. Ren, Y.; Yu, M.; Wu, C.; Wang, Q.; Gao, M.; Huang, Q.; Liu, Y. A comprehensive review on food waste anaerobic digestion: Research updates and tendencies. Bioresour. Technol. 2018, 247, 1069-1076. [CrossRef]

6. Silvestre, G.; Rodríguez-Abalde, A.; Fernández, B.; Flotats, X.; Bonmatí, A. Biomass adaptation over anaerobic co-digestion of sewage sludge and trapped grease waste. Bioresour. Technol. 2011, 102, 6830-6836. [CrossRef] 
7. Ma, X.; Yu, M.; Song, N.; Xu, B.; Gao, M.; Wu, C.; Wang, Q. Effect of ethanol pre-fermentation on organic load rate and stability of semi-continuous anaerobic digestion of food waste. Bioresour. Technol. 2020, 299, 122587. [CrossRef]

8. Xu, R.; Xu, S.; Florentino, A.P.; Zhang, L.; Yang, Z.; Liu, Y. Enhancing blackwater methane production by enriching hydrogenotrophic methanogens through hydrogen supplementation. Bioresour. Technol. 2019, 278, 481-485. [CrossRef]

9. Lim, J.W.; Chiam, J.A.; Wang, J. Microbial community structure reveals how microaeration improves fermentation during anaerobic co-digestion of brown water and food waste. Bioresour. Technol. 2014, 171, 132-138. [CrossRef]

10. Zhang, Q.; Zhang, L.; Guo, B.; Liu, Y. Mesophiles outperform thermophiles in the anaerobic digestion of blackwater with kitchen residuals: Insights into process limitations. Waste Manag. 2020, 105, 279-288. [CrossRef]

11. Kujawa-Roeleveld, K.; Elmitwalli, T.A.; Zeeman, G. Enhanced primary treatment of concentrated black water and kitchen residues within DESAR concept using two types of anaerobic digesters. Water Sci. Technol. 2006, 53, 159-168. [CrossRef]

12. Luostarinen, S.; Rintala, J. Anaerobic on-site treatment of kitchen waste in combination with black water in UASB-septic tanks at low temperatures. Bioresour. Technol. 2007, 98, 1734-1740. [CrossRef] [PubMed]

13. Lavagnolo, M.C.; Girotto, F.; Hirata, O.; Cossu, R. Lab-scale co-digestion of kitchen waste and brown water for a preliminary performance evaluation of a decentralized waste and wastewater management. Waste Manag. 2017, 66, 155-160. [CrossRef] [PubMed]

14. Wang, X.; Gabauer, W.; Li, Z.; Ortner, M.; Fuchs, W. Improving exploitation of chicken manure via two-stage anaerobic digestion with an intermediate membrane contactor to extract ammonia. Bioresour. Technol. 2018, 268, 811-814. [CrossRef] [PubMed]

15. APHA. Standard Methods for the Examination of Water and Wastewater, 19th ed.; American Public Health Association: Washington, DC, USA, 1995.

16. Gao, M.; Guo, B.; Zhang, L.; Zhang, Y.; Liu, Y. Microbial community dynamics in anaerobic digesters treating conventional and vacuum toilet flushed blackwater. Water Res. 2019, 160, 249-258. [CrossRef] [PubMed]

17. Lu, X.; Zhen, G.; Liu, Y.; Hojo, T.; Estrada, A.L.; Li, Y. Long-term effect of the antibiotic cefalexin on methane production during waste activated sludge anaerobic digestion. Bioresour. Technol. 2014, 169, 644-651. [CrossRef] [PubMed]

18. Hu, Y.; Pang, Y.; Yuan, H.; Zou, D.; Liu, Y.; Zhu, B.; Chufo, W.A.; Jaffar, M.; Li, X. Promoting anaerobic biogasification of corn stover through biological pretreatment by liquid fraction of digestate (LFD). Bioresour. Technol. 2015, 175, 167-173. [CrossRef]

19. Liu, T.; Zhou, X.; Li, Z.; Wang, X.; Sun, J. Effects of liquid digestate pretreatment on biogas production for anaerobic digestion of wheat straw. Bioresour. Technol. 2019, 280, 345-351. [CrossRef]

20. Kim, J.; Baek, G.; Kim, J.; Lee, C. Energy production from different organic wastes by anaerobic co-digestion: Maximizing methane yield versus maximizing synergistic effect. Renew. Energy 2019, 136, 683-690. [CrossRef]

21. Du, X.; Tao, Y.; Li, H.; Liu, Y.; Feng, K. Synergistic methane production from the anaerobic co-digestion of Spirulina platensis with food waste and sewage sludge at high solid concentrations. Renew. Energy 2019, 142, 55-61. [CrossRef]

22. Zhang, L.; Guo, B.; Zhang, Q.; Florentino, A.; Xu, R.; Zhang, Y.; Liu, Y. Co-digestion of blackwater with kitchen organic waste: Effects of mixing ratios and insights into microbial community. J. Clean. Prod. 2019, 236, 117703. [CrossRef]

23. Rajagopal, R.; Lim, J.W.; Mao, Y.; Chen, C.; Wang, J. Anaerobic co-digestion of source segregated brown water (feces-without-urine) and food waste: For Singapore context. Sci. Total Environ. 2013, 443, 877-886. [CrossRef] [PubMed]

24. Wendland, C.; Deegener, S.; Behrendt, J.; Toshev, P.; Otterpohl, R. Anaerobic digestion of blackwater from vacuum toilets and kitchen refuse in a continuous stirred tank reactor (CSTR). Water Sci. Technol. 2007, 55, 187-194. [CrossRef]

25. Wu, C.; Wang, Q.; Yu, M.; Zhang, X.; Song, N.; Chang, Q.; Gao, M.; Sonomoto, K. Effect of ethanol pre-fermentation and inoculum-to-substrate ratio on methane yield from food waste and distillers' grains. Appl. Energy 2015, 155, 846-853. [CrossRef] 
26. Fuchs, W.; Wang, X.; Gabauer, W.; Ortner, M.; Li, Z. Tackling ammonia inhibition for efficient biogas production from chicken manure: Status and technical trends in Europe and China. Renew. Sustain. Energy Rev. 2018, 97, 186-199. [CrossRef]

27. Kayhanian, M. Ammonia Inhibition in High-Solids Biogasification: An Overview and Practical Solutions. Environ. Technol. 1999, 20, 355-365. [CrossRef]

28. Shanmugam, P.; Horan, N.J. Optimising the biogas production from leather fleshing waste by co-digestion with MSW. Bioresour. Technol. 2009, 100, 4117-4120. [CrossRef]

29. Silvestre, G.; Illa, J.; Fernández, B.; Bonmatí, A. Thermophilic anaerobic co-digestion of sewage sludge with grease waste: Effect of long chain fatty acids in the methane yield and its dewatering properties. Appl. Energy 2014, 117, 87-94. [CrossRef]

30. Zhang, C.; Su, H.; Baeyens, J.; Tan, T. Reviewing the anaerobic digestion of food waste for biogas production. Renew. Sustain. Energy Rev. 2014, 38, 383-392. [CrossRef]

31. Pan, Y.; Zhi, Z.; Zhen, G.; Lu, X.; Bakonyi, P.; Li, Y.; Zhao, Y.; Rajesh Banu, J. Synergistic effect and biodegradation kinetics of sewage sludge and food waste mesophilic anaerobic co-digestion and the underlying stimulation mechanisms. Fuel 2019, 253, 40-49. [CrossRef]

32. Mehariya, S.; Patel, A.K.; Obulisamy, P.K.; Punniyakotti, E.; Wong, J.W.C. Co-digestion of food waste and sewage sludge for methane production: Current status and perspective. Bioresour. Technol. 2018, 265, 519-531. [CrossRef]

33. Zhang, W.; Wei, Q.; Wu, S.; Qi, D.; Li, W.; Zuo, Z.; Dong, R. Batch anaerobic co-digestion of pig manure with dewatered sewage sludge under mesophilic conditions. Appl. Energy 2014, 128, 175-183. [CrossRef]

34. El-Mashad, H.M. Kinetics of methane production from the codigestion of switchgrass and Spirulina platensis algae. Bioresour. Technol. 2013, 132, 305-312. [CrossRef] [PubMed]

35. Wang, X.; Li, Z.; Zhou, X.; Wang, Q.; Wu, Y.; Saino, M.; Bai, X. Study on the bio-methane yield and microbial community structure in enzyme enhanced anaerobic co-digestion of cow manure and corn straw. Bioresour. Technol. 2016, 219, 150-157. [CrossRef] [PubMed]

36. Kassab, G.; Khater, D.; Odeh, F.; Shatanawi, K.; Halalsheh, M.; Arafah, M.; van Lier, J.B. Impact of Nanoscale Magnetite and Zero Valent Iron on the Batch-Wise Anaerobic Co-Digestion of Food Waste and Waste-Activated Sludge. Water 2020, 12, 1283. [CrossRef]

(C) 2020 by the authors. Licensee MDPI, Basel, Switzerland. This article is an open access article distributed under the terms and conditions of the Creative Commons Attribution (CC BY) license (http://creativecommons.org/licenses/by/4.0/). 